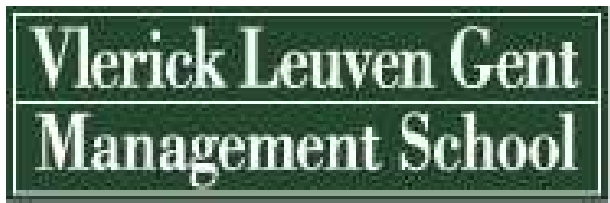

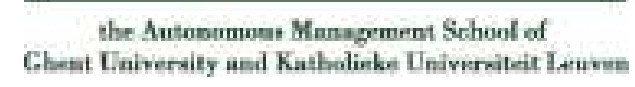

Vlerick Leuven Gent Working Paper Series 2009/27

\title{
TO WHAT EXTENT IS THE FINANCIAL CRISIS A GOVERNANCE CRISIS?- FROM DIAGNOSIS TO POSSIBLE REMEDIES-
}

\author{
LUTGART VAN DEN BERGHE \\ Lutgart.VanDenBerghe@vlerick.be
}

\begin{abstract}
'The credit bubble was not just a simple market failure, but a failure of business leadership, corporate governance and risk management, exacerbated by flawed incentive structures with banks" (John Plender, Financial Times, 22 August 2008).
\end{abstract}




\title{
TO WHAT EXTENT IS THE FINANCIAL CRISIS A GOVERNANCE CRISIS?- FROM DIAGNOSIS TO POSSIBLE REMEDIES-
}

\author{
LUTGART VAN DEN BERGHE \\ GUBERNA \& Vlerick Leuven Gent Management School
}

\footnotetext{
Contact:

Lutgart Van den Berghe

Vlerick Leuven Gent Management School

Tel: +32092109896

Fax: +32092109700

Email: Lutgart.VanDenBerghe@ vlerick.be
} 


\begin{abstract}
The post-Enron period is characterised by increased efforts in strengthening corporate governance. In the wake of the financial crisis, however, the effectiveness of these (governance) reforms is put into question. Although the financial crisis seems to be caused by macro-instabilities and micro regulatory failures, it can be argued that governance failures aggravated the financial meltdown. This paper discusses the systemic governance failures that can (partly) explain the financial crisis and provides insights into the lessons to be learned. The analysis highlights four main deficiencies: (i) inadequate monitoring by the market in combination with an 'open' shareholder model; (ii) the perverse side-effects of (variable) performance-related incentive schemes that were supposed to be the disciplinary mechanism per excellence for (top) managers; (iii) insufficient risk modelling and risk management which leads to poor external and internal supervision with regard to risk exposure and (iv) governance investments were too much focused on structures and procedures instead of on stimulating the right corporate behaviour and attitude. Furthermore, possible remedies to restore trust in the business world are being discussed. This includes -amongst others- a reflection on mechanisms that foster company-wide long-term value creation; proper risk assessment encompassing a true audit of strategic risks; a reconsideration of board roles and board composition, thereby paying more attention to leadership and personality issues; etc. Finally, the paper argues that the balance between regulation and self-regulation is at stake.
\end{abstract}


Over time, the development and refinement of corporate governance standards and recommendations have often been the consequence of corporate governance failures. Even if the collapse of Enron and the like, may not have been caused by corporate governance failures in a strict sense, there were serious deficiencies that facilitated or at least did not prevent such disastrous business practices. New legislation (like Sarbanes-Oxley and the European governance directives) and an impressive set of governance recommendations (European recommendations and numerous national governance codes) were developed to cure the governance deficiencies identified. The new legislations and recommendations of the post-Enron era implied important investments in new governance structures and procedures. This gave lean way to the expectation in the business world and society at large that the efficiency and effectiveness of governance would drastically increase. It is therefore all the more disturbing that those remedies have not been able to prevent the financial turmoil.

Although the root causes of the financial crisis seem to lay in macro instabilities excessive liquidity and cheap money- and micro regulatory failures, numerous studies also point to governance failures, which -at least- aggravated the financial meltdown. According to the EU-report of the de Larosière Group (2009) ${ }^{1}$, corporate governance is one of the most important failures behind the present financial crisis. Also the OECD (2009b) clearly pointed to corporate governance failures as an important factor behind the financial collapse: 'This Report concludes that the financial crisis can be to an important extent attributed to failures and weaknesses in corporate governance arrangements." The prominent international shareholders' association, ICGN (2009b), stated that it is now widely agreed that corporate governance failures were not the only cause of the financial crisis, but were highly significant. Other investors ${ }^{2}$ state that corporate governance did not cause the financial crisis (macroimbalances did), but certainly aggravated the crisis. In a report to the G20, Becht $(2009 ; 2)$ stated that the current financial crisis is a classic example of board failure on strategy and oversight, misaligned or perverse incentives, empire building, conflicts of interest, weaknesses in internal controls, incompetence and fraud.

\footnotetext{
1 'The high-level group on financial supervision in the EU', chaired by Jacques de Larosière, published its Report to the European Commission on February 25, 2009.

${ }^{2}$ Peter Montagnon (ABI \& European Corporate Governance Forum) defended this view at the European Commission's Round Table on Director Remuneration on 23 March 2009.
} 
Whether we like it or not, the societal backlash of these failures goes far beyond the financial sector. Society is loosing trust in business leaders in general and is heavily criticizing their societal behaviour, condemning their huge remuneration packages and the lack of effective board oversight.

Therefore, everyone interested in effective governance has to further reflect on the lessons to be learned and on the possible remedies to restore (societal) trust in the business world. Besides our ambition of contributing to such deeper reflection, it is our goal to go beyond the symptoms and investigate the more systemic governance failures. It is clear that those governance failures are not the monopoly of the financial sector. On the contrary, the systemic governance failures could be relevant for all types of business activities and organisations. So the lessons to be learned and the possible remedies do have a far larger scope than financial institutions alone.

Without having the intention neither to moralise on business practices nor to follow the societal revolt or the classical hunt for the guilty, we can not deny that even in companies that formally complied with most of the governance recommendations, things went wrong. As in the previous cycle, we can again try to analyse the underlying governance failures and investigate possible remedies. However, we have to notice that some of the previous remedies were insufficient and/or had (unforeseen) side-effects that made things even worse. Consequently we would like to point out that governance mechanisms should be critically evaluated on a regular basis, their side-effects be investigated and -where necessary- be drastically adapted. However, we should be aware that even strengthened governance cannot guarantee absence of corporate problems in the future. 


\section{CORPORATE GOVERNANCE MAY NOT/NO LONGER RELY ON THE ASSUMPTION THAT THE 'MARKET WILL TAKE CARE OF IT'}

\section{Governance codes adhere to market discipline}

The leading (Anglo-American) corporate governance literature and the corporate governance codes for listed companies depart from the assumption that the market is the final disciplinary mechanism to guarantee that firms are governed in the best interest of their owners. In corporate finance and corporate governance this paradigm has long been defended, in the sense that listing at the stock exchange could only evolve towards a perfect market in as far as the shareholdership was completely open, dispersed and volatile. Such capital structure guaranteed that the requirements of market operation were optimally fulfilled, i.e. a large number of market parties that could not significantly influence the market price (dispersed shareholdership), shares that were often traded (high liquidity, thanks to high velocity and free float) and companies without any inside shareholders (who could take advantage of their controlling position to detract private benefits), but with outsiders that monitored the listed company on the base of equal information (fair disclosure) and in complete transparency.

For a long time, corporate governance overwhelmingly focused on such types of open listed firms. Notwithstanding that the majority of listed companies all-over the world is still relying on inside shareholders (blockholders), there was a push towards more open, dispersed and anonymous shareholders. Governance best practices referred to open dispersed shareholdership as the bench mark. Governance ratings promoted open dispersed shareholders and disliked controlling shareholders and stable blockholding, penalising such companies with a lower governance rating.

\section{Curing the hurdles on the route to perfect markets}

But of course hurdles could exist on the route towards open market transactions. Therefore legislation had to guarantee that such barriers be eliminated and governance remedies had to be tailored to reach the goal of open financial markets. 
Specific governance recommendations had to cure potential hurdles. Outside shareholders can only play their role as final gatekeeper of sound governance practices, if they possess a sufficient insight into the company, they invest in. Transparency rules are a first governance remedy allowing market parties to play their role. However companies with a dispersed shareholding structure have to cope with the collective action problem of passive, uninterested small shareholders ${ }^{3}$. Therefore, institutional investors are urged to play a more active role in disciplining the good governance of listed companies (see e.g. the ERISAlegislation in the US, obliging public pension funds to use their voting rights). In practice, even the largest institutional investors hold relatively small stakes, so that it becomes hard to justify investing large amounts of money in monitoring their portfolio companies. Another remedy is the famous 'pay for performance' solution has been promoted to make sure that managers focused more on the interest of the dispersed shareholders. Besides board oversight (to promote shareholder' interests) the last and ultimate discipline on management should be the market for corporate control: a manager that is only pursuing its self-interest while neglecting the shareholders' interests can loose his job when the shareholders decide to sell the firm. Therefore no barriers should exist towards free trade in companies!

Each of these remedies shows downsides, weaknesses and/or unintended negative side-effects, proving over and over again that the assumption of perfect markets is unsustainable!

\section{The financial crisis showed much deeper flaws in the perfection of (financial) markets}

Recently the perfect market paradigm has come under severe attack. In his most recent publication, George Soros (2008) pleads for a complete revision of this market fundamentalism. Markets do not operate perfectly, not only because information is incomplete but foremost because the market parties can play a disturbing role (reflexivity) on the market outcome. Their beliefs and previsions may substantially deviate from reality (intentionally influencing, if not even misleading other market parties) and this will affect the final outcome adversely and is at the origin of boom- and bust cycles.

\footnotetext{
${ }^{3}$ Governance is often defined as the 'resolution of collective action problems among dispersed investors'; see Becht $(2009 ; 5)$.
} 
The financial sector is all the more vulnerable in this respect, because expectations do play a very important role in the market operations. If financial markets are completely free this often leads to cycles of euphoria and desperation. Speculation, day trading and short selling can be seen as market corrective, but are often also disturbing a stable market output and market prices that no longer reflect the underlying value of the company or the asset.

Looking at the actual financial crisis, cheap money (a Keynesian recipe to cure the crisis after the Internet bubble) seems to be at the origin ${ }^{4}$ of an unprecedented credit expansion, amplified and accelerated by complex and opaque financial innovation (from securitisation to artificial financial products). Consequently we witnessed important asset inflation, leading to a boom-bust bubble in all types of real and financial markets. The crisis erupted when monetary policy tightened, making capital more expensive

\section{IFRS: from a solution for better market transparency ...}

In academic research as well as in business calculations, value is defined from a market perspective (what is the market capitalisation, the company's value to a potential shareholder, a potential buyer, etc.) or from an accounting perspective. The market value can considerably differ depending on the market sentiment (cfr. boom and bust cycles). Former accounting principles where more historically oriented (with valuations based on historic cost and economic depreciation principles) and offered more opportunities for stabilising provisions, hereby allowing to neutralise volatile business cycle effects. However, such smoothing principles were considered opaque, not allowing outsiders to have a fair view on the underlying market value of the company. Modern IFRS-accounting is much more market oriented too (here again we feel the pressure of valuation for open market transactions) with consequently more volatility.

As has already been explained earlier, transparency is the corner stone for efficient capital markets. Conditional upon such a market mechanism is to have a level playing field for all shareholders with sufficient and transparent information on the value of the corporation. Shareholders -as outsiders- have to rely on such market information to decide on their selling and buying of stocks. IFRS accounting rules have become instrumental in this respect.

\footnotetext{
${ }^{4}$ According to the EU-report presented by the 'de Larosière Group' (2009), the major underlying factor behind the financial crisis of 2008 is the fact that there was ample liquidity (thanks to the huge inflow of funds from countries such as China and the Middle-East) and very low interest rates.
} 
Such rules proclaim that at any moment in time, outsiders should be aware of the true market value of all components of the corporation, while any form of internal reservation had to be abolished because this led to incomplete information for outside shareholders.

\section{..., to potentially adverse affects}

However, it is questioned whether important components of the IFRS-approach, like the fair value concept is fair at all. Such market-oriented valuation system has its downside, in that it is subject to increased volatility (pro-cyclicality) and negative spill-over effects, certainly in times of boom and bust. These adverse effects hold for the upside as well as for the downside trends ${ }^{5}$. Potential capital gains (market value above original cost or historic value) have to be accounted for, leading to an upswing in virtual profitability and reserves with potentially higher variable remuneration and dividend pay-outs, if not share buy-backs. The more such increase in asset prices are the effect of speculation and asset bubbles the more dangerous this capital distribution process becomes.

The opposite (vicious) circular effects are noticed when market values substantially decrease. Accounting rules helped trigger a negative feed-back loop that amplified the downside effect of financial markets (de Larosière, 2009), leading to capital losses, need for impairments, depreciations and lower virtual profitability, eventually necessitating extra capital buffers, 'fire sales' while also limiting the growth and financing capacities. Moreover the more a company is judged on its short-term (quarterly) market value, the faster the downward spiral goes, when things go wrong. This vicious circle can become a systemic risk when it comes to financial institutions which heavily rely on mark-to-market operations for investments and financing. The question is therefore often raised to what extent the volatility syndrome of IFRS has been the fire that worsened the world-wide financial crisis (Wymeersch, 2008; Heremans in Killemaes and Mouton, 2008).

\footnotetext{
5 According to the EU-report presented by the 'de Larosière Group' (2009;8), 'the rapid recognition of profits, which accounting rules allowed, led both to a view that risks were falling and to increases in financial results. This combination made institutions vulnerable to changes in valuation as economic circumstances deteriorated.
} 


\section{From loopholes in the regulatory approach and insufficient insights into financial innovations ...}

In the post-communist era the free market fundamentalism won world-wide support far outside the sphere of the capital market. Economic policy at national and international level focused on optimal market operations and on the elimination of all relevant barriers to free competition (cfr EU liberalisation policy; cfr. abolishment of the Glass-Steagall act in the US). In such an era self-regulation was the route to complement a retreating supervision and regulation. The underlying paradigm of this free market movement is that markets can better regulate themselves because the invisible hand (the self-interest) of the rational market parties will lead to the optimal market outcome.

The supremacy of market thinking has convinced regulators to draw back and rely more on self-regulation within the financial sector. The end of the Glass Steagal Act in the US has allowed investment banks to become active within the financial arena, while also allowing regular banks to become involved in much more types of investment banking. Moreover regulatory paradises continued to prosper for firms like hedge funds and the like, not being subjected to any regulation, regular depository banks have been faced with. But also depository banks have found a way around stricter regulation, by focusing more and more attention on 'modern' banking, preferably outside the perimeter of tough (solvency) rules. Numerous inventive and artificial investment vehicles were created, which allowed offbalance transactions, engagements and leverage to grow exponentially, while at the same time being so complex that even standard risk models were no longer a valid tool for supervision. The standard model for calculating solvency requirements, foreseen in the Basle I rules, has been largely replaced by the Basle II facility to use internal risk models. Such flexibility again led to a larger degree of freedom causing at the same time a far more complicated supervision. According to the de Larosière report to the EU (2009), the definition of capital requirements placed too much reliance on both the risk management capabilities of financial institutions and on the adequacy of ratings while not sufficiently incorporating the macro-systemic risk of contagion. After the facts, one can observe that risks proved to be much higher than the internal models had expected! 


\section{...to a general plea for more and tougher regulations, also outside the financial sector}

Due to the loopholes in the regulation of financial market players and the serious monitoring mismatch, the cry for more and tougher regulation is loud and clear. Illustrative in this respect is the view of Sarkozy (2008): 'L'autorégulation pour règler les problèmes, c'est fini. Le laissez-faire, c'est fini. Le marché a toujours raison, c'est fini.

Although there are many arguments in favour of such extra regulation, the danger is that this will not be limited to the financial sector. To the extent that the origin of the crisis is more systemic to the financial sector, it should be questioned whether enlargement of the regulatory impact outside the financial institutions is justified. Self-regulation has the great advantage of flexibility, offering the possibility to tailor to the diverging and changing needs of the business world. Moreover, soft law may finally have more teeth than originally assumed, e.g. when jurisprudence is developed with reference to these self-regulatory principles. On top of that, boards of directors and shareholders that formally adhere to the governance principles will considerably increase the strength of self-regulation (Wymeersch, 2008).

In first instance, we should therefore try to encompass all relevant additional points of attention (e.g. remuneration, risk management) into the self-regulatory approach of governance codes. However, one can not be blind that some governance failures will necessitate complementing that self-regulation with additional regulation (e.g. on transparency). The EU sees the need for further regulation in two respects. The credit rating agencies, which greatly underestimated the risk exposures of banks, should be subjected to a registration within the EU as well as to external oversight. Another point for further regulation is remuneration. Since only 1 out of 3 member states seem to follow the EU recommendation on director remuneration, there is a need for some urgent measures, certainly in the financial sector. The EU will investigate clearer policy guidance in this respect, including shareholder voting on some remuneration issues. 


\section{Growing interdependence due to globalisation and repackaging of securities}

If there is one sector where globalisation has been realised to a large extent, it is the financial sector. Complex webs of companies, joint ventures and the like have been built around the world. However with the interrelationship between all players and with the interwoven products came also an important increase of vulnerability and systemic risk. Moreover with regulatory oversight still being mainly national, controlling such interlocking relationships and complex interdependencies, became very complex, if not impossible.

The distance between the real economy and the financial economy has become that large that any feeling for proportion and economic sense seems to have been drifting away with every expansion of the financial system.

\section{In search for mechanisms to focus more on long term value creation and corporate responsibility}

Value creation is a crucial term in defining corporate success and in judging the quality and performance of a corporation, its management and its board. However, defining what value creation means, is not straight forward at all. What kind of value should be the reference base and how should we measure such important indicator? This discussion touches upon the 'raison d'être' of corporations and will be differently answered whether you are a day trader, a hedge fund, a family owner, an employee or a customer, to name only a few quite different views..

Even hard defenders of open market transactions were not blind for the potential downsides of a too hard focus on self-interest and short term profit. Illustrative in this respect is the ground work of Adam Smith. In his 'Theory of moral sentiment' (1759) he clearly pointed to the fact that the driver of market operations and economic development, being profit, should be complemented with non-profit values. A market can only operate effectively if there is mutual trust between market parties and such trust is built on values such as fairness, human attitude, generosity, eye for the public good, etc. According to Adam Smith, the government had to play the role of watchdog and where private markets would fail, government needs to complement the supply of products and services (i.e. providing public goods). 
According to Eddy Wymeersch $(2008 ; 1)$ the corporate governance debate remains constrained to the private interests of the parties involved and does not include the public good that may be affected by company decisions ${ }^{6}$. Notwithstanding some (rather marginal) socially responsible investment funds (SRI's), capital markets traditionally attach most importance to the value created for the (public) shareholders. In the actual discussion of the financial crisis one of the main critiques on the market parties is that they -by far- focused too much on short-term value creation, at the detriment of huge risk exposures, while also ignoring the long-term and societal effect.

There seems to grow a general consensus that shareholders should become more supportive of the long-term effects of business decisions and choices. Companies with stable shareholders (like controlling shareholders) will probably have a far easier task in convincing their shareholders than those with mostly short-term traders as capital providers. But society is putting the heat on and is even going one step further in the direction of corporate social responsibility. The pressure is on companies to educate their shareholders so that they become more receptive, if not supportive of long-term value creation, including considerations on shareholder as well as stakeholder value.

Taking into consideration the devastating externalities (societal and economic spillover effects) of the financial sector, there is a plea to consider the 'general interest' when developing governance structures and processes within financial institutions ${ }^{7}$. However some do make a clear distinction between the spill-over effects of financial institutions on financial and economic stability in general and the far broader concept of corporate social responsibility and ethical business behaviour. In this respect Eddy Wymeersch (2008;4) states that the concept of 'ethics' is usually too elusive to be considered a usable yardstick, at least in legal terms. Moreover the contribution to financial stability is quite different from CSR where no clear political authority is exercised, and where the use of corporate governance instruments is based on a largely voluntary approach.

\footnotetext{
${ }^{6}$ Becht (2009) states that 'corporate governance at the firm level, was never designed to internalize contributions to systemic risk'. This is all the more important in sectors facing such important risk, but in fact is relevant in any firm engendering important external effects ((dis-)economies).

${ }^{7}$ In this respect, Freddy Van den Spiegel (Fortis) (in Pironet, 2009) refers to the previous regulation in the Belgian Financial Sector that tried to improve the autonomy of boards of directors. In order to compensate for the impact of board representatives from the reference shareholders, regulation foresaw that all executives had to be part of the board of directors.
} 
However, several frameworks for socially responsible business and reporting have been developed all-over the world. The OECD recently stated (2009a) that the global landscape of international initiatives to promote responsible business practice has become increasingly -and perhaps confusingly- crowed over the last decade. Such CSR-reporting focuses on the value creation from an economic (profit), social (people) and societal (planet) perspective. Contrary to this growing attention for corporate social responsibility reporting, most of the world-wide discussions on corporate governance ignore the ethical and stakeholder perspective. There have rarely been bridges between the traditional financial and governance frameworks at the one hand and the socially responsible reporting frameworks at the other hand ${ }^{8}$. In the future, governance codes will have to attach more attention to this 'enlightened shareholder value' approach.

The omission of an ethical and stakeholder perspective allows organisations to focus on short-term shareholder value, stock price and quarterly results. Although more nuanced approaches exist everywhere, most of the players in the financial world are (were?) adepts of the classical free market thinking. As already highlighted before, market fundamentalism leads to a nearly blind belief in the law of the market, also when it comes to the governance of market operations and market parties. As already stated by the founder of the open market transactions, Adam Smith, when ethics and integrity lack, the market can no longer operate as a good governance mechanism and capitalism dares to become casino-capitalism. Neglecting the long-term effect of corporate decision-making and totally ignoring the ethical dimension of profit maximisation are (partly) explanations for the mortgage-crisis in the US. The mere fact that they operated with so-called 'teaser rates' (very low initial interest rates) clearly proves that such practices were far from oriented towards long-term customer interests.

\footnotetext{
${ }^{8}$ In this respect we would like to point to our proposal for a 'socially responsible corporate governance', published in 'Corporate Governance in a globalising world: convergence or divergence? A European perspective', Kluwer Academic Publishers, 2002.
} 
But the short-term disease is more widespread than in this mortgage-crisis. Financial firms, capital markets, financial analysts and large shareholder organisations have put the accent far too much on creating short-term shareholder value, as if it was the ultimate goal of the firm. In the absence of long-term shareholders, most listed companies are driven, if not biased by the share price and sometimes worse, making important choices and decisions on the base of the potential effect on the next quarter results. Interesting in this respect is the view of the de Larosière Group (2009): 'It is clear that the financial system at large did not carry out its tasks with enough consideration for the long-term interest of its stakeholders. Shareholders' pressure on management to deliver higher share prices and dividends for investors meant that exceeding expected quarterly earnings became the benchmark for many companies' performance. The accounting system (IFRS) is facilitating and even supporting such short term valuation approach, while remuneration systems were further accentuating this focus.'

Even the international shareholders' association, ICGN (2009a \& 2009b) recognizes that the financial crisis was exacerbated by a failure of governance, both within bank boards and, in some cases, by lack of engagement of shareholders, responsible for governance oversight. They propose an elaborated set of shareholder responsibilities, such as explicit recognition of their responsibility to generate long term value, putting sufficient resources into governance that delivers long term value, taking governance factors as well as risk factors into consideration.

The financial crisis showed that controlling shareholders or blockholders ${ }^{9}$ are -after all- not that bad when it comes to be a stabilising factor in times of turmoil, while giving preference to the long-term value creation over the short-term optimisation. Long-term shareholders are considered to have a more disciplinary impact on risk appetite (Heremans in Killemaes and Mouton, 2008), generating a more natural self-control (Colmant, 2008b), because of their more concentrated risk and their more important exposure to the well-being of the company. This does not imply at all that such type of controlled listed companies can not and do not suffer from specific governance challenges, such as the potential of making abuse of a controlling position, or depriving the company of growth perspectives because of the mantra of the controlling position of blockholders.

\footnotetext{
${ }^{9}$ According to Becht $(2009 ; 8)$ large shareholders with a strong economic interest and voting rights are also a powerful approach to mitigating the collective action problem of dispersed shareholders. They have an interest in monitoring the board and through the board management. However there is a fundamental tradeoff between these advantages and the danger of abuse of a powerful position of these large shareholders.
} 


\section{REMUNERATION SYSTEMS: FROM A DISCIPLINARY GOVERNANCE REMEDY TO PERVERSE SIDE-EFFECTS}

\section{Performance-related pay as a governance remedy,...}

The open capital market with dispersed shareholders embedded the danger that listed companies were directed by strong managers, while suffering from weak owners. Therefore, governance remedies had to be developed to make sure that (independent) managers were taking care of the ultimate goal of creating shareholder value. The board of directors had to make sure that managers were sufficiently disciplined and controlled. Performance-related executive remuneration was perceived to be the most important disciplinary mechanism in this respect. If managers would be generating more income conditional upon a shareholder value increase, this would engender them to stimulate shareholder value.

\section{...with important side-effects}

However, the remedy turned out to be sometimes worse than the sickness it had to cure! Such variable remuneration systems are not only open to management influence and sometimes outright manipulation they also can lead to short-term optimisation and overly risky behaviour.

Already after Enron and comparable fraud cases, the governance codes made a plea for a more thorough board reflection on remuneration issues. The OECD governance principles e.g. recommend that executive (and board) remuneration should be aligned with the longer term interests of the company and its shareholders and that a remuneration policy statement should specify the relationship between remuneration and performance (including measurable performance standards). However significant this evolution may be, one may not forget that the problem has not been sufficiently cured yet.

More attention should be given to controlling the spill-over effects of executive remuneration structures. Remuneration practices are one of the important reasons for the financial crisis, according to the de Larosière report to the EU (2009). 
The OECD report on the financial crisis (2009b) highlighted that "remuneration systems have in a number of cases not been closely related to the strategy and risk appetite of the company and its longer term interests ${ }^{10} \ldots$ Incentive systems encouraged and rewarded high levels of risk taking, and as such worsened the failures of the risk management systems".

Another complicating if not aggravating effect on performance measurement came from the accounting rules. Such rules induce a systematic bias towards short-term performance, because they allowed immediate recognition of mark-to-market profit without necessitating a discount for future potential losses. As a result of all this, the long-term, "through the cycle" perspective has been neglected.

\section{But there is much more at stake than executive remuneration}

It is insufficient to focus only on the remuneration of top executives. Many organisations, not in the least those in the financial sector, have rolled-out the variable remuneration system to many other levels of the organisation. The OECD analysis of the financial crisis (2009b) clearly states that remuneration systems lower down the management chain might have been an even more important issue than the executive remuneration.

Also the de Larosière report to the EU (2009) stated that remuneration and incentive schemes within financial institutions contributed to excessive risk-taking by rewarding shortterm expansion of the volume of (risky) trades rather than the long-term profitability of investments. Most of the incentives encouraged financial institutions to act in a short-term perspective and to make as much profit as possible to the detriment of credit quality and prudence.

At whatever level, if greediness reigns, variable remuneration systems can become devastating for the long-term success and even the stability of the firm.

\footnotetext{
${ }^{10}$ To some extent, the OECD seems less severe than e.g. de Larosière Group in their judgement on the negative effect of the executive remuneration structure.
} 


\section{In search of possible remedies}

It is certainly premature to formulate already definite routes to solve such an important problem as the 'pay-for-performance'. Unfortunately there is today more heat than light in the public debate around incentives and remuneration structure (Kirkpatrick, 2009). In such a climate of societal revenge, referring to top managers as the new 'barbarians', there is huge pressure to regulate and limit (executive) remuneration (by setting maximum amounts, maximum multiples and/or by huge tax rates). As stated by the de Larosière Group (2009) we should not have the illusion that regulation alone will allow solving such huge problems.

Thanks to the numerous proposals on the table ${ }^{11}$ and the intensive debate around executive remuneration and bonus payments ${ }^{12}$, we can already detect a number of key elements of possible remedies. We would like to group them in the following categories: first and foremost the substance discussion on the remuneration policy (why and which type of variable remuneration) second, the process and conditions to develop and apply such remuneration policy and finally the transparency issues.

\section{- $\quad$ The substance discussion on remuneration policy}

On top of the existing guidelines and formalities defined in the governance codes, more reflection is necessary on the remuneration policy especially from the perspective of the remuneration structure and severance pay. In most of the cases, it is not so much a discussion on the level of the remuneration itself (although this has caused most societal and political discussions) but on the remuneration structure, mainly in the light of potential downsides and spill-over effects or unintended consequences.

A first point of reflection is to clearly define the type of performance measures or criteria that form the basis for the variable remuneration. Should they be financial or also include non-financial elements? Should the financial criteria focus on shareholder value and be market-based or (also) include accounting and budgetary criteria? There is an overwhelming agreement that whatever criteria used, one should make sure that companywide long-term value creation is sufficiently taken into consideration.

\footnotetext{
${ }^{11}$ In this respect we would like to refer to the detailed analysis of the OECD report (2009b) and de Larosière Group (2009) as well as to the recent proposal of the European Corporate Governance Forum (2009b) and the UK Financial Services Authority (2009). In the UK, the supervisor of the financial sector, the FSA, has launched a draft Code of practice on remuneration policies. The principles set forward in this Code will be instrumental in defining eligibility for government support of financial institutions and, once accepted, they will be used for judging the risk profile and necessary capital buffer of ALL financial institutions. Even UK-subsidiaries of foreign companies are obliged to install a remuneration committee.
} 
Interesting best practices point to the use of a balanced score card approach to design variable remuneration systems. This is also the proposal developed by the UK financial services authority in their recent draft remuneration guidelines: "Firms should not assess performance solely on the results of the current year and also non-financial performance metrics should form a significant part of any variable remuneration system. Sufficient attention should be paid to the quality of the business, its risk profile, its sustainability and suitability for the client. Therefore a balanced scorecard is a good instrument in this respect." (FSA, 2009). Suggestions also include using a multi-year framework for the assessment of bonuses $^{13}$ and extending the period for the vesting of stock options. But attention for the fiscal aspects of such proposals will be necessary. Given the huge differences in tax treatment of the variable remuneration components it will be very hard to come to an international level playing field in this respect.

A second condition is to design a variable remuneration policy that supports sound risk management. If there is only an upside to the performance-related pay system, managers and employees will be stimulated to go for the upside, even if this comes at the detriment of a much higher risk and the long term success of the company. Moral hazard is a well-known concept in insurance economics and is a relevant reflection when it comes to discussing the downside-effects of remuneration incentives (Bostyn, 2008)

The UK proposal for the financial sector gives detailed recommendations to develop remuneration policies that are risk-focused (for the bonus as well as for the long-term incentive plan). The aim is to ensure that firms have remuneration policies which are consistent with effective risk management, and which do not expose them to excessive risktaking by staff (so explicitly going beyond the executive level ${ }^{14}$ ). Poor remuneration policies can lead to implicit or explicit expectations of performance from the employee, which are misaligned with the firm's risk appetite and contrary to sound risk management. Concrete proposals include the focus on profits, adjusted for current and future risk and taking into account the cost of capital employed and the liquidity required. Other suggestions are introducing a bonus-malus philosophy and claw-back clauses.

\footnotetext{
12 The European Commission organised a Round Table on Director's Remuneration on 23 March 2009.

${ }^{13}$ In the de Larosière Group report (2009) the suggestion is given to use a 5-year approach towards bonuses.

${ }^{14}$ It is clearly stated that the field of reference therefore goes beyond executive remuneration and presumably encompasses all types of variable remuneration.
} 
Principles of Conduct for Compensation Policies (International Institute of Finance (2008)

1. Compensation incentives should be based on performance and should be aligned with shareholder interests and long term, firm-wide profitability, taking into account overall risk and the cost of capital

2. Compensation incentives should not induce risk-taking in excess of the firms risk appetite.

3. Payout of compensation incentives should be based on risk-adjusted and cost of capital-adjusted profit and phased, where possible, to coincide with the risk time horizon of such profit.

4. Incentive compensation should have a component reflecting the impact of business unit's returns on the overall value of related business groups and the organisation as a whole.

5. Incentive compensation should have a component reflecting the firm's overall results and achievement of risk management and other goals.

6. Severance pay should take into account realised performance for shareholders over time.

7. The approach, principles and objectives of compensation incentives should be transparent to stakeholders.

However, integrating risk management into the remuneration system will necessitate much harder changes, than merely adding a risk management specialist to the remuneration committee. The whole performance management approach will have to be expanded in order to integrate the right risk profiles (Visser, 2008). Even with a balanced score card, the framework will have to be complemented with critical risk indicators for each of the critical performance indicators.

If it is true that much of the financial crisis problems go back to corporate behaviour, short-term focus and greed being ingrained in the incentive structure, the challenge is even more huge, i.e. to change corporate attitude and behaviour. More attention should therefore be paid to the alignment of the remuneration system and structure (criteria to be integrated in defining management performance and variable remuneration) with corporate values (relevant definition of value creation) as well as with the criteria set forward in attracting top management (such as leadership, integrity, etc.) (Verbeke, 2009).

Or should we look for more drastic solutions, like abolishing all complex formula of variable remuneration or limiting the relative weight of variable remuneration? A number of suggestions can shed more light on possible routes ahead. 
For what concerns 'supervisors', like the risk management function or independent directors, international proposals plead for determining their (variable) remuneration independently of business performance ${ }^{15}$. Also the practices with smaller listed companies (often with inside, controlling shareholders) and non-listed companies can be worthwhile to study as potential best practices. Most of these companies combine the benefits of variable remuneration (stimulating performance, effectiveness and efficiency) without the numerous side-effects. The relative weight of their variable remuneration is mostly quite lower than in the large listed companies (Baeten, 2008), while at the same time often capping the maximum amount of such variable remuneration. It is very interesting to observe that the UK Financial Services Authority came to a comparable conclusion, when studying the necessary improvements to the remuneration policy of financial firms. They proposed that the fixed component of the remuneration should be sufficiently high to allow the company to operate a fully flexible bonus policy. Recent OECD-research in the financial sector revealed a huge reliance on variable remuneration, on average around $75 \%$ at European banks, but $94-96 \%$ in US banks!

Another innovation suggested (Van de Cloot in BZB, 2009) is to introduce a kind of 'bonus-malus' provision for the variable part, whereby variable remuneration can even be negative in certain crisis years. Spreading the payment over a rather long time, this would allow for a more stabilised remuneration. But some commentators do point to the danger of 'punishing' management for entrepreneurial ventures that prove to turn out worse than expected. It is crucial that there remains sufficient entrepreneurship within any firm, and this basically necessitates the willingness to take entrepreneurial risk. So the solution proposed would be to agree upon the degree of risk appetite and honour entrepreneurship as long as the ex-post risk profile is within the boundaries set (Visser, 2008).

\section{- $\quad$ The process to develop and apply a remuneration policy}

In this respect an important question is "who is responsible for what part of the remuneration puzzle?'. What is the role of the board of directors and of the remuneration committee, do shareholders have a 'say on pay' and what input should be expected from executive management and from external remuneration consultants? The responsibilities of

\footnotetext{
${ }^{15}$ In the UK proposals for remuneration practices in financial institutions it is proposed that compensation for staff in the risk and compliance functions should be determined independently of the business areas. They should have different performance metrics, with greater emphasis on the achievement of their own objectives.
} 
both external monitors and internal monitors are at stake and should be carefully revisited in order to find solutions to cure the problem.

For what concerns the internal monitors, the first duty rests with the board of directors and its remuneration committee. Designing the remuneration structure and setting the levels of remuneration is first and foremost a matter for the board. The EU-recommendation on director remuneration already pointed to the important role of the remuneration committee (in listed $^{16}$ companies) and the conditions on its composition (independence from management) and functioning (executives should not be involved in setting their own remuneration). However, failures of executive remuneration policies necessitate additional recommendations, such as a more careful examination of the potential risks and down-side effects of variable remuneration. Remuneration committees should specifically analyse the danger of excessive risk-taking and short-termism to the detriment of long-term performance. Illustrative in this respect is the UK Financial Services Authority draft Code which fosters sufficient attention for the potential side-effects of variable remuneration on risk taking. They propose that at least one member of the remuneration committee should have practical skills and expertise of risk management and that there should be regular reporting from the firm's risk manager. Moreover independent supervision on the risk-adjustment factors necessitates more attention for the status of the top risk manager and his remuneration.

Aside from the huge tasks on the shoulders of the boards of directors, also shareholders should play their part in curing the problem. Shareholders' activism has been growing and they want a 'say on pay'. Therefore issues of transparency and involvement of shareholders in important remuneration discussions seem an important step forward. However, it is also fair to say that shareholders, when judging business performance, should become more supportive of the long-term success of the firm. Companies with stable shareholders (like controlling shareholders) will probably have a far easier task in convincing their shareholders than those with mostly short-term traders as capital providers. Stating, like the de Larosière report (2009) that 'it is important to re-align compensation incentives with shareholder interests and long-term, firm-wide profitability' is probably less straight-forward than assumed!

\footnotetext{
${ }^{16}$ In the UK draft Code of practice on remuneration policies in the financial sector, even UK-subsidiaries of foreign companies will be obliged to install a remuneration committee.
} 
Remuneration consultants have been criticised for their upward effect on executive remuneration. They facilitated positioning executive remuneration at above median market levels, with comparisons focusing on top remunerated peers. Such market references induced a continuous international upward trend. In its 2003 study on corporate governance, the Economist Intelligence Unit referred in this respect to the so called 'Lake Wobegon Effect' (after Garrison Keillor's mythical US prairie town where 'all the children are just above average'). Every company is assumed to pay 60 to $70 \%$ of average compensation for whatever peer group their consultant defines, thus constantly ratcheting up pay. The $2009 \mathrm{UK}$ draft code on remuneration in financial firms explicitly stated that the need for firms to offer competitive remuneration packages is recognised, but that industry comparators should be a secondary rather than a primary factor in the determination of the remuneration. Many commentators want the board of directors to take a far more active role in judging the effectiveness and fairness of a remuneration policy. Moreover, if they are to rely on external consultants they should pay far more attention to their independence in relation to management. In this respect, experience should be gained with the solutions found in the postEnron slipstream to cope with the many conflicts of interest between audit firms and their clients. The remuneration committee could be inspired by the audit recommendations and critically evaluate the independence of remuneration advisors.

\section{- $\quad$ The transparency internally and externally}

The remuneration committee will be asked to provide evidence of how well its remuneration policies measure against these new principles, together with plans for improvement where there is a significant shortfall. In its annual remuneration report they will also be asked to report on the 'people risk'. The statement should include an assessment of the impact of their remuneration policies on behaviour, and on the risk profile of the firm. In drawing up this assessment, boards and remuneration committees should exercise their own judgement and not rely solely on the judgement or opinions of others. It would be good practice to make such report available to the shareholders.

Up till now the emphasis has merely been on information to shareholders and external market comparisons in judging the fairness of executive and variable remuneration. The spillover effect of this external transparency has been a heavy public discussion, increasingly focusing on the societal fairness of such compensation. This societal heat will be taken over by trade unions and employees who will demand remuneration committees to also reflect on internal fairness and transparency. 


\section{LARGE FAILURES IN RISK MODELLING AND RISK MANAGEMENT}

In a financial market with plenty liquidity and low interest rates, investors as well as financial players were actively searching for higher yields, accepting more risk. At first, securitisation has been considered to be the 'nec plus ultra' of financial innovation. It allowed credit institutions and insurance companies to enlarge their debt capacity at attractive prices (also with respect to the necessary solvency capital). For investment banks it was a very lucrative type of business, because it allowed them becoming financial engineers in packaging and repackaging assets with different categories of risk profile. But also for credit rating agencies a new market could be developed with tailored ratings for each of those categories of collateralised debt. But we may not forget that everybody was benefiting from these developments. Coupled with cheap money, global risk spreading in different layers had a beneficiary effect on the cost of capital. Consequently business firms as well as private households could increasingly rely on cheap money and high credit leverage. Shareholders pushed companies to increase their degree of financial leverage, preferably by buying back shares or paying out super dividends.

\section{Fundamental failures in the assessment of risk, ...}

There have been quite fundamental failures in the assessment of risk, both by financial institutions and by those supervising them. Risk became mis-priced from several perspectives. Risk structures of securitised assets were approved and granted a good rating without tough scrutiny of the quality of the counter parties involved. Issuers seemed to shop around to get the best rating, while credit rating agencies were subject to conflicts of interest, rather than being able to express independent judgements. In the 'originate-to-distribute model', where the lender knew beforehand that he would transfer or sell the portfolio and/or the default risk through collateralized debt structures, there was no incentive to ensure high lending standards, leading to a severe weakening of underwriting standards. Moreover it was assumed that global risk spreading over numerous layers and parties was supposed to almost, if not fully, eliminate the risks involved.

Proper risk assessment was very difficult and opaque for external and internal supervisors not in the least because of the extreme complexity of such structured products, their numerous layers and parties involved (there was little knowledge of either the size or the location of credit risks, not knowing whether risk had been really spread or simply reconcentrated in less visible parts of the system). 
But even worse, the risk models used by financial institutions and credit rating agencies assumed stable markets, hereby completely ignoring systemic risk (underestimation of correlations in the defaults that would occur during a downturn, e.g. the collateralized mortgage obligations assumed that the prices of real estate would not be subject to negative spiral effects). We have all witnessed that the reality in the financial markets is much more instable and vulnerable to so-called 'Black Swans', e.g. no bank expected a total freezing of the inter-bank or commercial paper markets (dixit the de Larosière report; 2009). The silo approach of risk assessment per type of product or line of business induced an insufficient awareness of the firm-wide exposure and the correlations between different risk factors.

\section{..., aggravated by failures in corporate governance}

The OECD (2009b) Steering Group on Corporate Governance has pinpointed the failures in risk management as the most important diagnosis of the financial crisis, but this failure is largely attributed to weaknesses in corporate governance, more than to defaulting risk assessment or risk models. "When they were put to a test, corporate governance routines did not serve their purpose to safeguard against excessive risk taking in a number of financial services companies. The risk management systems have failed in many cases due to corporate governance procedures rather than the inadequacy of computer models alone."

The OECD (2009b) identified the following weaknesses: information about exposures in a number of cases did not reach the board and even senior levels of management, while risk management was often activity rather than enterprise-based. These are board responsibilities. In other cases, boards had approved strategy but then did not establish suitable metrics to monitor its implementation. Company disclosures about foreseeable risk factors and about the systems in place for monitoring and managing risk have also left a lot to be desired (even though this is a key element of the OECD Governance Principles).

Although this analysis focused on the financial institutions, the lessons learned can be relevant for each board of directors. A critical examination of the risk management capacities of a board of directors should at least touch upon the following questions:

$\Rightarrow$ Has the board obtained the relevant information?

$\Rightarrow$ Is there a solid risk culture throughout the firm with clear emphasis on the respective roles of the $\mathrm{CEO}$ and the board?

$\Rightarrow$ Are board members sufficiently literate on business risk? 


\section{Beyond board level, a lack of internal governance}

In its most simple approach, 'corporate' governance, is about how a firm is directed and controlled. The numerous corporate governance codes around the world mainly focus on the corporate board of directors as the main vehicle to reach good corporate governance, with some minor attention for the relationship with and the respective role of shareholders and top management, while ignoring most, if not all other layers (internal organisation, business units, operating companies, subsidiaries, joint ventures, etc). The basic rules of corporate governance recommend sufficient checks and balances, segregation of functions and accountability for delegated decision-making power. However, insufficient attention has been paid to the necessity to apply these rules to ALL levels of decision-making. The huge attention paid to compliance with corporate governance codes and regulations is ineffective without a well-developed system of 'internal' governance.

The famous Sarbanes-Oxley act (agreed upon with near unanimity of the US-Congress as the remedy to the corporate crisis around Enron, WorldCom etc) was a first attempt to regulate the internal governance aspects from the perspective of internal control and risk management. After some years, all firms listed in the US as well as their world-wide operating companies, have been faced with tougher rules on risk management and internal control. But also the OECD governance principles have attached special attention to the fact that the monitoring role of the board includes continuous review of the internal structure of the company "to ensure that there are clear lines of accountability for management throughout the organisation". This internal governance aspect has presumably not received the attention it deserves ${ }^{17}$.

But even with tough internal control and risk management there are huge challenges boards of directors and top management face in today's complex (financial) business world. The more complex and global such groups become and the more sophisticated product innovations are, the more unrealistic it is to assume that a limited number of top people and directors at corporate level can follow-up and completely oversee such global web of organisations and complex products.

\footnotetext{
${ }^{17}$ Although the Basel Committee (and some national banking supervisors) developed specific internal governance recommendations (see e.g. http://www.bis.org/publ/bcbs122.htm).
} 
The OECD (2009b) reports that risk issues are increasingly becoming too specialist for meaningful oversight by the whole board. We therefore need to reflect on ways to make decision-makers at all levels in the organisation more aware of, if not responsible for, the short as well as the long-term effects of their choices and decisions, without killing their entrepreneurship and creativity. If accountability and governance rules are not deployed to all relevant levels of a complex organisation, no top management, directors, nor shareholders can have a quiet night sleep.

Or have we reached a level where diseconomies of scale and scope become devastating? This is e.g. the thesis defended by Eric de Keuleneer (2009). Louis Verbeke (2009) stated that we underestimated the cost of complexity (in part driven by size). Should we also not review the loss of control and knowledge caused by outsourcing, reduction of headquarters, etc? Charting such complexity costs seems necessary to reach optimal business decisions. Ultimately it is the total architecture which may be at stake, including globalisation and the internal governance consequences which come with it (like supply chain efficiency and accountability for it).

\section{Insufficient discussion on the strategic risks and on defining the corporate risk appetite}

Notwithstanding the huge investments in compliance with tougher audit and risk management prescriptions, it seems that such rules have been unable to prevent a serious financial crisis. An additional explanation could be that business practice does not sufficiently tackle all the relevant and important risk exposures. The OECD (2009b) analysis pointed to the fact that board of financial institutions had approved strategy but did not establish suitable metrics to monitor its implementation. Research and board experience in different sectors demonstrates that internal control and risk management systems mainly devote attention to managing financial and operational risk, but do ignore most of the 'strategic' risks. This is clearly also the opinion of the OECD (2009b), who state that "attention in recent years has focused on internal controls related to financial reporting and on the need to have external checks and reporting... It needs to be stressed, however, that internal control is at best only a subset of risk management and the broader context, which is a key concern for corporate governance, might not have received the attention that it deserved, despite the fact that enterprise risk management frameworks are already in use.” Ralph Ward (2009) puts it differently: 'Sarbanes-Oxley changes focused boards closely on compliance and disclosure rules, while they missed big management strategic blunders'. 
Management should facilitate that the board can exercise its responsibility to oversee the complete risk exposure and to decide on the risk appetite of the corporation. The board must ensure that risk appetite is a coherent reflection of the company's strategic targets. In making important board decisions on strategic choices, directors should be faced with a true audit of the strategic risks involved, with different possible scenarios and their underlying risks and assumptions as well as with the overall firm-wide risk exposure.

From a theoretical perspective, the Enterprise Risk Model encompasses all types of risks. However, the auditors and internal control departments mostly focus on traditional financial and operational risk management, ignoring most of the time the strategic risks. What could have caused this omission? Didn't they have the right expertise to do so, or were they not involved, nor consulted to advise on strategic risks? In some cases, the OECD research (2009b) has observed that boards were not aware of important strategic decisions or were not sufficiently informed on the complete risk exposure, etc. But also boards need to understand the firm's business strategy from a forward looking perspective, not just review current risk issues and audit reports.

\section{Ignoring the behavioural aspect of risk management}

The analysis of the failures in corporate risk management is incomplete if one should not also point to the behavioural dimensions. It seems that the lower prestige and status of risk management staff vis-à-vis traders and sales people played an important role in suppressing the efficient information and discussion of risk exposure in financial institutions. The de Larosière Group proposed several (procedural) remedies to improve risk monitoring and sound risk management. The top or senior risk managers should have a high-ranking status and be allowed to have a direct line with the board of directors (comparable to the internal auditor). The chief risk officer should have direct access to the board and the audit committee (as is already the case for the internal auditor).

Another remedy being that companies should move towards a culture of shared responsibility and mutual respect. 
It is essential that there is a culture to pass all relevant information on risk exposure and possible red flags to the top layers of the organisation, a mentality to share quantitative and qualitative information more efficiently across the firm and to engage in a more effective dialogue across the firm. 'Bad news should travel fast' has been the successful recipe of many long-standing family business firms ${ }^{18}$

But also the remuneration of the (chief) risk officer(s) deserves further attention. It is said that effective checks and balances are unlikely to work if those who are supposed to control risk remain under-paid, compared to those whose job it is to take risks. The Financial Services Authority in the UK goes one step further in proposing that their remuneration structure should eliminate possible conflicts of interest. For risk managers their variable remuneration should not refer to any business output measure but depend upon risk management indicators.

\section{GOVERNANCE MECHANISMS: INSUFFICIENT FOCUS ON SUBSTANCE AND TOO MUCH ATTENTION FOR FORMALITIES}

In its study of the corporate collapses at the beginning of this century (Enron and the like), the Economist Intelligence Unit (2003) concluded that 'companies are putting in place new governance processes but these processes do not necessarily lead to substantive changes; the form-over-substance problem is exemplified by efforts to supercharge the audit committee;... rules and regulations may help shore up confidence in the market but they will not magically produce good behaviour'. Six years later, the OECD steering committee on corporate governance (2009b) poses the question whether boards are up to their huge tasks, while the Institute of International Finance (2008) concluded that events have raised questions about the ability of certain boards to properly oversee senior management and to understand and monitor the business. These are potentially worrying conclusions, which necessitate far more in-depth reflection on governance failures and possible remedies.

This is all the more problematic since the post-Enron era was characterised by an increased focus on the empowerment of the board of directors. Such empowerment was the red line through the governance codes, that were developed all-over the world.

\footnotetext{
${ }^{18}$ Corporate value fostered by the late Paul Fentener-van Vlissingen, former chairman of SHV, a family-owned conglomerate in the Netherlands.
} 
It is therefore understandable that numerous specialised studies mirror the disappointment of society at large with the ineffectiveness of these huge investments in governance structures and procedures. The governance codes and regulations seem to have been unable in preventing the financial meltdown. As described before the potential factors that caused the financial crisis are far more complex than mere governance failures alone. However, we should be honest in stating that a number of shortcomings in the governance practice have accelerated the financial collapse.

\section{In search of the right attitude and behaviour}

The main critique on the effectiveness of governance in general and of board of directors more specifically is that boards failed to understand and manage risk, while at the same time tolerating perverse incentive systems. But also shareholders are not free of critique. They are blamed for having tolerated such board behaviour while at the same time allowing, if not stimulating huge leverage levels and a short-term focus.

Overlooking such analyses, we have to conclude that these deficiencies finally boil down to corporate behaviour and deploying the right governance attitude. Such goal can hardly be reached by regulation or legislation. As stated by ICGN (2009b) reform is as much about behaviour as it is about prescription. We will -whether we like it or not- have to rely on improving the focus of the governance codes and on redefining best practices. We are certainly not lacking governance codes and recommendations, but up to now they have focused on 'structural' governance factors, such as composition of the board of directors, CEO-Chair duality, independent directors, presence of board committees and the like. Best practices were defined with reference to this 'easy to check' input characteristics. However, substance should reign over form.

Board effectiveness and the quality of governance are also, if not more, driven by the right governance processes and the right attitude. But this attention for corporate attitude and behaviour does not stop at the board of directors or at the level of top management. On the contrary, everybody should be involved in this attitude focus. The mindset, the ethical attitude, the integrity of people do necessitate much more attention in order to guarantee that good structures, good principles and processes also get applied in practice (so discipline is important). Combining corporate with internal governance is also from this perspective the broader framework we should all look for. But the right tone and the right culture should start at the top! 
The right governance attitude encompasses also the right tone towards shareholders: not overly promising, nor creating unrealistic expectations. At the same time managers will have to educate their shareholders and try to withstand short-term market pressures. Strong managers have a straight back in defending long-term strategies and investments, even if short-term oriented shareholders/sharetraders would pressure them to act otherwise.

\section{In search of the right balance in the board's role}

The numerous governance codes introduced considerably more duties, commitment and time investment ${ }^{19}$ for directors. Although the board's role has drastically increased the last decade boards are criticized for having been too complacent and unable to prevent the collapse of a number of financial institutions.

In the light of the previous analysis of the governance failures, we should reconsider the right balance of duties of a board of directors.

There is foremost a need to reconsider the primordial role of board when it comes to having the right leadership. Much more attention should be paid to the personality of the top people: do they have the right attitude, the right alignment with corporate values, ambitions, corporate strategy and the time horizon (long-term versus short-term optimisation)? To this end, the board's role does not stop with the nomination of the top manager(s). Non-executive directors should also critically monitor and evaluate management in the light of these principles, including decisions on their remuneration, while at the same time being supportive of management. This in itself is certainly a delicate balance!

When it comes to their strategic role, they should make sure that a thorough discussion of the strategic scenario's and routes includes sufficient attention for the specific risk/performance profile; clearly defining the specific risk appetite of the firm.

The monitoring of corporate performance and reporting should pay attention to financial as well as to non-financial reporting, to audit, internal control and risk management. One of the duties of the board is to have a very clear understanding of the final goals of the firm, considering criteria to evaluate the long-term shareholder value as well as the impact on the relevant stakeholders. Such (balanced score card?) framework should be applied whenever important strategic decisions have to be made, as well as when monitoring the execution and the results they entailed. 


\section{In search of the right balance in board composition}

Although independence of the board remains an important ingredient of corporate governance, it should be clear that independence has been the only important characteristic the codes have relied upon. This is incomplete from two respects.

First of all, independence may not come at the detriment of sufficient business insight, expertise and know how of the strategic challenges and risk of the business portfolio. The OECD report (2009b) refers to a head hunter, stating that "one of the unintended consequences of Sarbanes Oxley is that its emphasis on independence rules out from board positions a lot of people who knew about this business". This coincides perfectly with the statement made by Emilio Botin (2008), the Chairman of Banco Santander: "For years, the idea of a mostly independent board was promoted as a hallmark of good governance: the best director was the one most removed from the business because he was the most independent. That was the wrong approach".

In their governance analysis the de Larosière Group (2009) explicitly states that failures in risk assessment and risk management were aggravated by the fact that the checks and balances of corporate governance also failed. Many boards and senior managements of financial firms neither understood the characteristics of the new, highly complex financial products they were dealing with, nor were they aware of the aggregate exposure of their companies, thus seriously underestimating the risks they were running. Many board members did not provide the necessary oversight or control of management, nor did the owners of these companies - the shareholders. Also the OECD report (2009b) points to the lack of sufficient expertise on the boards and especially on specialist risk and audit committees of failing organisations. The fact that there are recently many changes in board composition is used to prove the correctness of this diagnosis.

Ironically, the large number of non-executives on boards may have made it more difficult - not easier - for external directors to influence boardroom decision-making. The more numerous external directors become the more unitary boards tend to limit the number of executive directors, to the CEO, eventually complemented by the CFO.

\footnotetext{
${ }^{19}$ In a recent publication (L'Expansion, 2009), Daniel Lebègue, chairman of IFA (the French Institute of Directors), stated that directors should consider investing about 2 months per year in a board mandate in a larger company.
} 
The dominance of the CEO becomes often greater, as there is less scope for external directors to develop working relationships with senior members of management. It may also be easier for a CEO to manage the information flow to the rest of the board. Non-executive directors are at an inherent disadvantage relative to executive management, due to the parttime nature of the role and their position outside the organisational structure. They invariably rely on company insiders for information and expertise. Regardless of their independent stature as individuals or their achievements in other sectors or professions, they will face an uphill struggle in credibly challenging executive management. It is possibly no coincidence that the two areas of the economy which have been subject to volatile cycles of boom and bust over the last decade - financial services and technology - are both sectors of activity that are potentially highly opaque to non-specialist board members. According to Roger Barker (2009), the emphasis that has been placed on independence - as if it was the only thing that mattered - in corporate governance codes, European directives, and public discourse has created unrealistic expectations of what boards can achieve. Looking forward, the holy grail of boardroom design should not be independence, but boardroom competence and professionalism.

Secondly the codes have not paid sufficient attention to the importance of personality and attitude issues. When overly stressing independence and the need for critical attitude and positions this can lead to board processes that are at odds with a consensus-driven decisionmaking in a collegial (one-tier) board. More attention should also be paid to the right tone at the top not only for top managers, but for directors as well. All should adhere to and apply the principles of integrity and responsible business leadership. For all levels in the organisation the choice of people is key. Such choices have to be based on a personality fit with the corporate values, the strategic goals and challenges and be translated into all evaluation and remuneration systems. Evaluation of board effectiveness as well as the monitoring and remuneration of top managers should attach much more importance to these 'soft' elements; a hard job but all the more rewarding in the long run! 


\section{Conclusions and recommendations for further reflection}

Although the root causes of the financial crisis seem to lay in macro instabilities excessive liquidity and cheap money- and micro regulatory failures, numerous studies also point to governance failures, which -at least- aggravated the financial meltdown. This is all the more cumbersome since the post-Enron period was characterised by huge attention for corporate governance. Were the recommendations insufficient or incorrect, were they not sufficiently adopted or was it a combination of the two?

This reflection note has been trying to look into the governance symptoms behind the financial crisis. However we also tempted to go one step further, demanding whether systemic governance failures could (partly) explain the financial crisis. In doing so, we came to the conclusion that those systemic governance deficiencies were already present at the time of Enron and comparable corporate debacles. So the preliminary conclusion may well be that the post-Enron governance recommendations have been curing the symptoms but have not sufficiently tackled the underlying systemic failures. It is time for a more thorough reflection on some of the 'holy myths' of the governance religion.

\section{Corporate Governance may not/no longer rely on the assumption that the 'market will take care of it'}

An essential ingredient of corporate governance best practices is that there should be sufficient checks and balances. The governance tripod, composed of top management, board of directors and shareholders is exemplary in this respect. Shareholders delegate power down to the board, which delegates executive power to top management. The accountability lines go all the way up from management to the board and from the board to the shareholders. In such a capitalist system the shareholders are the final monitors of the company. Once a company goes for listing on the stock exchange, it is assumed that the market becomes the final disciplinary mechanism. Since inside shareholders could take advantage of their controlling position to detract private benefits, outside shareholders are the final monitors of the listed company. In order for outsiders to perform this important monitoring role all shareholders should have equal access to information (fair disclosure) and there should rein complete transparency about all important business aspects. Since a perfect capital market necessitates that market parties can not significantly influence the market price, the capital structure should evolve in the direction of widely dispersed shareholdership. 
The price system will work best when there is a high liquidity built on a high velocity, shares being regularly traded and the free float being high.

Although these governance characteristics are supported by governance literature as well as by international governance ratings, it is doubtful that such dispersed, anonymous and volatile shareholders can be the final monitors of the listed companies. In a fully dispersed shareholder model, management and 'their' directors evolve into an autocratic governance model with insufficient checks and balances. The debacle of some financial firms, but also the Enron and comparable fraud cases -at the beginning of this century- suffered from this 'strong managers - weak owners' syndrome'. That such models are prone to excessive executive remuneration is nearly self-evident.

However, these observations may not lead us to the conclusion that listing at the stock exchange should be abolished. On the contrary, we should look for preserving the benefits of listing, without being blind for the numerous potential deficiencies of such governance structures. The myth that the market will take care of it has made us blind about the potential downsides of such open capital structure. Once we realise that each governance model has its potential deficiencies (as well as it positive contributions) we can start developing tailored governance recommendations (that should cure these potential downsides). If we compare the strengths and weaknesses of insider and outsider models, it is clear that a hybrid combination of two needs to be further studied. Shareholder activism is essential to sufficiently monitor a firm's governance and performance. A minimum level of relatively stable shareholders with a long-term valuation horizon seems necessary to cure the collective action problems, dispersed shareholders are confronted with. Such types of shareholders can be found with family shareholders as well as with industrial and institutional shareholders. At the same time, sufficient attention should be paid to guarantee that all shareholders are fairly treated and that there is fair disclosure and full transparency to outside as well as inside shareholders.

\section{Remuneration systems: from a disciplinary governance remedy to perverse side-effects}

In open listed companies, strong managers need to be disciplined, in order to sufficiently take care of the interests of the dispersed shareholders. If managers would be generating more income conditional upon an increase in shareholder value, this would align their interests with those of the shareholders. So, performance-related incentives became the disciplinary mechanism par excellence. 
However, the remedy turned out to be sometimes worse than the sickness it had to cure! In managerial governance models, such variable remuneration systems are open to management influence and sometimes to outright manipulation (like in the case of Enron e.g.). The financial crisis proved (again) that variable remuneration can lead to short-term optimisation and overly risky behaviour. Moreover, such short-term sub-optimisation may well have been aggravated by the IFRS-accounting rules. In order to have a level playing field for all shareholders, there is need for totally transparent information on the valuation of a listed company. So, fair value accounting saw the light. In a boom and bust cycle such market-oriented valuations may lead to pro-cyclicality and increased volatility. Potential capital gains (market value above original cost or historic value) have to be accounted for, leading to an upswing in virtual profitability and reserves. But even worse, such virtual profit may easily be distributed through higher variable remuneration, super dividend pay-outs and share buy-backs. What a dangerous capital distribution process!!!

The financial crisis taught us that it is insufficient to focus only on curing the problem of executive remuneration. Many organisations, not in the least those in the financial sector, have rolled-out the variable remuneration system to many other layers of the organisation.

After Enron and comparable fraud cases, the governance codes made a plea for a more thorough and independent board reflection on remuneration issues. However significant this evolution may have been, one can not ignore that the problem has not been sufficiently cured yet. Unfortunately there is today more heat than light in the public debate around incentives and remuneration structure. In such a climate of societal revenge, there is huge pressure to regulate and limit (executive) remuneration (by setting maximum amounts, maximum multiples and/or by huge tax rates). We should not have the illusion that regulation alone will allow solving such huge problems. Three main lines of corrective actions are open for further reflection: What are the components of a remuneration policy and system? How should the process to develop and implement such a system look like? What are the necessary transparency and accountability rules?

Developing a remuneration system necessitates a thorough reflection on the definition of value creation. Value creation touches upon the 'raison d'être' of corporations and will be differently answered whether you are a day trader, a hedge fund, a family owner, an employee or a customer, to name only a few quite different views. Such definition is extremely important for the selection of the correct performance measures or criteria that have to form the basis for the variable remuneration. The financial crisis has turned the focus away from short-term share value indicators. 
There seems to grow an overwhelming agreement that whatever criteria used, one should make sure that the drivers behind company-wide long-term value creation are sufficiently taken into consideration. Interesting best practices point to the use of a balanced score card approach to define a variable remuneration system. A second condition is to design a variable remuneration policy that supports sound risk management. Variable remuneration should not expose to excessive risk-taking at any level. However, integrating risk management into the remuneration system will necessitate much harder changes, than merely adding a risk management specialist to the remuneration committee. The whole performance management approach will have to be expanded in order to integrate the right risk dimensions. Even with a balanced score card, the framework will have to be complemented with critical risk indicators for each of the critical performance indicators.

Numerous solutions and possible remedies have already been suggested to cure the perverse side-effects of variable remuneration. Some make a plea for limiting the relative weight of variable remuneration or for setting a maximum cap on (total) variable remuneration. In order to integrate the possible downside into variable remuneration, suggestions are made to introduce a bonus-malus provision that will smooth positive and negative variable remuneration. A longer term horizon would be introduced with the obligation to develop a multi-year framework for the assessment of bonuses as well as to extend the period for the vesting of stock options. Claw-back clauses could give the company the right to oblige managers to pay back variable remuneration that has been incorrectly paid out (e.g. due to misrepresentation of performance). If it is true that much of the remuneration problems go back to corporate behaviour, the challenge is even more huge, i.e. to change corporate attitude and behaviour Or should we look for more drastic solutions, like abolishing all complex formula of variable remuneration?

In designing the process to be followed, an important question is "who is responsible for what part of the remuneration puzzle?' What is the role of the board of directors and of the remuneration committee, do shareholders have a 'say on pay' and what input should be expected from executive management and from external remuneration consultants? The responsibilities of both external monitors and internal monitors are at stake and should be carefully revisited in order to find solutions to cure the remuneration problems. For what concerns the internal monitors, the first duty rests with the board of directors and its remuneration committee. New recommendations include an interactive collaboration of the remuneration committee with the chief risk officer in order to analyse the risk profile associated with the performance criteria set forward. 
To this end, the remuneration committee should have a risk expert in its midst. Remuneration consultants should be subjected to tougher criteria of independence (towards management) and their remuneration comparisons need to be judged more critically (a secondary rather than a primary source of comparison). But also shareholders do have an important role to play in curing the problem of myopic short-termism and overly risky ventures. Re-alignment will be harder with short-term oriented shareowners/traders than with long term shareholders.

Increased shareholder as well as societal pressure for corporate accountability and transparency on (executive) remuneration will probably induce tougher rules than ever before. The ghost is out of the bottle and it will be hard, if possible at all, to get him back in the bottle. Boards will have to evolve from a disclosure -style 'show me'- to a 'prove me' style of accountability. The remuneration committee will be asked to provide evidence of how well its remuneration policies measure against the new governance principles. Where there is a significant shortfall, they will have to come up with plans for improvement. Coupled with the increased call for external credibility, there will also be an increasing demand for internal transparency. The traditional external market fairness examinations will have to be complemented with a thorough analysis of the internal fairness in executive remuneration!

\section{In search for mechanisms to focus more on long term value creation and corporate responsibility}

The combination of short-term volatile shareowners and performance-related incentives has been a dangerous cocktail behind the financial crisis. One of the main critiques on the financial market parties is that they -by far-focused too much on short-term value creation, at the detriment of huge risk exposures, while also ignoring the long-term and societal effect. In the absence of long-term shareholders, most listed companies are driven, if not biased by the share price and sometimes worse, making important choices and decisions on the base of the potential effect on the next quarter results.

Contrary to the growing attention for corporate social responsibility, most of the world-wide discussions on corporate governance ignore the ethical and stakeholder perspective. There have rarely been bridges between the traditional financial and governance frameworks at the one hand and the socially responsible reporting frameworks at the other hand. 
The corporate governance debate remains constrained to the private interests of the parties involved and does not include the public good that may be affected by company decisions. There seems to grow a general consensus that shareholders should become more supportive of the long-term effects of business decisions and choices. The pressure is on companies to educate their shareholders so that they become more receptive, if not supportive of long-term value creation and sustainability. Paying attention for devastating externalities is certainly necessary in sectors like the financial sector, where financial stability can be seen as a public good. In such cases directors should (be obliged to) take the general interest into consideration, when making important business decisions. But more generally, all boards of directors should attach sufficient attention to the respect of the interests of the relevant stakeholders hereby stimulating the creation of 'enlightened' shareholder value.

\section{Large failures in risk modelling and risk management, aggravated by governance} failures

In a financial market with plenty liquidity and low interest rates, investors as well as financial players were actively searching for higher yields, accepting more risk. Moreover, risk became mis-priced from several perspectives. Assets were granted a good rating without tough scrutiny of the quality of the counter parties involved. In the 'originate-to-distribute model' there was no incentive to ensure high lending standards. Moreover it was assumed that global risk spreading over numerous layers and parties was supposed to almost, if not fully, eliminate the risks involved. Financial institutions and credit rating agencies assumed stable markets, hereby completely ignoring systemic risk.

Proper risk assessment was very difficult and opaque for external and internal supervisors. This is very disturbing since the post Sarbanes-Oxley time frame was characterised by huge investments in risk management and internal control. And these proved to be ineffective! Analyses of failing financial institutions showed numerous governance deficiencies. Information about risk exposures did not reach the board and even senior levels of management. Risk management was often activity or product rather than enterprise-based. Such silo approach of risk assessment induced an insufficient awareness of the firm-wide exposure and of the correlations between different risk factors. In other cases, boards had approved strategy but did not establish suitable metrics to monitor its implementation. Company disclosures about foreseeable risk factors and about the systems in place for monitoring and managing risk have also left a lot to be desired. 
It is of utmost importance that several routes for improvement are further investigated. A first observation is that business practice presumably has not sufficiently tackled all relevant and important risk exposures. Internal control and risk management systems mainly devote attention to managing financial and operational risk, but do ignore most of the 'strategic' risks. From a theoretical perspective, the Enterprise Risk Model encompasses all types of risks. However, reality is far from this theoretical model. Did the risk managers have the right expertise to tackle the strategic risks or were they not involved, nor consulted to advise on strategic risks? But also boards need to understand the firm's business strategy from a forward looking perspective, not just reviewing current risk issues and audit reports. Management should facilitate that the board can exercise its responsibility to oversee the complete risk exposure and to decide on the risk appetite of the corporation. They should make sure there is a true audit of the strategic risks, analysing different possible scenarios, each with its underlying risks and assumptions as well as with the overall effect on the firmwide risk exposure.

Another route for further improvement relates to internal governance. Although the famous Sarbanes-Oxley act as well as the OECD governance principles attached special attention to developing governance beyond the board level this internal governance aspect has presumably not received the business attention it deserves. Complex webs of companies, joint ventures and the like have been built around the world. With the interrelationship between players and products came also an important increase of vulnerability and systemic risk. The more complex and global corporations become and the more sophisticated product innovations are, the more unrealistic it is to assume that a limited number of top people and directors at corporate level can follow-up and completely oversee such global web of organisations and complex products. If accountability and governance rules are not deployed to all relevant levels of a complex organisation, no top management, directors, nor shareholders can have a quiet night sleep.

But whatever investments we should make in developing further the internal governance system, we may not ignore to raise even more fundamental questions: Have we not reached a level where diseconomies of scale and scope become devastating? Have we not underestimated the cost of complexity? Should we also not review the loss of control and knowledge caused by outsourcing, reduction of headquarters, etc? Charting such complexity costs should become intrinsically part of good governance practice. 
The analysis of the failures in corporate risk management is incomplete if one should not also point to the behavioural dimensions. The top or senior risk manager should have a high-ranking status and be allowed to have a direct line with the board of directors (comparable to the internal auditor). Another remedy being that companies should move towards a culture of shared responsibility and mutual respect.

\section{Governance mechanisms: insufficient focus on substance and too much attention for formalities}

The reports on the financial crisis pose the question whether boards are up to their huge tasks. Events have raised questions about the ability of certain boards to properly oversee senior management and to understand and monitor the business. This is all the more problematic since the post-Enron era was characterised by an increased empowerment of the board of directors. The critique on directors and managers mirrors the disappointment of society at large with the ineffectiveness of the investments in governance structures and procedures.

Overlooking such analyses, we have to conclude that most of the deficiencies finally boil down to fallacies in corporate behaviour and governance attitude. Curing such deficiencies can hardly be reached by regulation or legislation. We will -whether we like it or not- have to rely on improving the focus of the governance codes and on redefining 'Best Practices'. Up till now most best practices were defined with reference to 'easy to check' input characteristics, like the percentage of independent directors, the split of the function of CEO and board chair, the instalment of board committees and the like.

Board effectiveness and the quality of governance are also, if not more, driven by the right governance processes and the right attitude. Moreover, this attention for corporate attitude and behaviour does not stop at the board of directors or at the level of top management. On the contrary, everybody should be involved in this attitude focus.

There is a need to reconsider the primordial role of board when it comes to having the right leadership. Much more attention should be paid to the personality of the top people. The mindset, the ethical attitude, the integrity of people do necessitate much more attention At the same time managers will have to educate their shareholders and try to withstand short-term market pressures. Strong managers have a straight back in defending long-term strategies and investments, even if short-term oriented shareholders/sharetraders would pressure them to act otherwise. 
When it comes to the board's strategic role, directors should clearly define the specific risk appetite of the firm, making a thorough discussion of possible strategic scenario's, with sufficient attention for the specific risk/performance profile of each possible route ahead. In monitoring corporate performance, boards should pay attention to financial as well as to nonfinancial elements. One of the duties of the board is to have a very clear understanding of the final goals of the firm, considering criteria to evaluate the long-term shareholder value as well as the impact on the relevant stakeholders. Such (balanced score card) framework should be applied whenever important decisions and choices have to be made.

Finally, the board composition also deserves further reflection. Independence has been the most important characteristic the codes have relied upon. This is incomplete from two respects. First of all, independence may not come at the detriment of sufficient business insight, expertise and insight into the strategic challenges and risks of the business portfolio.

Analyses of the financial crisis point to the lack of sufficient expertise on the boards and especially on specialist risk and audit committees of failing organisations. Looking forward, the holy grail of boardroom design should not only focus on independence, but on boardroom competence and professionalism as well. Secondly the codes have not paid sufficient attention to the importance of personality and attitude issues and the need for a clear fit between board personalities, corporate values, strategic goals and challenges. Evaluation of board effectiveness as well as the monitoring and remuneration of top managers should attach much more importance to such 'soft' personality characteristics; a hard job, but all the more rewarding in the long run!

\section{In search for a right balance between regulation and self-regulation}

Due to the loopholes in the regulation of financial market players and the serious monitoring mismatch, the cry for more and tougher regulation is loud and clear. Although there are many arguments in favour of such extra regulation, the danger is that this will not be limited to the financial sector. To the extent that the origin of the crisis is more systemic to the financial sector, it should be questioned whether enlargement of the regulatory impact outside the financial institutions is justified. 
On the other hand, we have demonstrated that numerous deficiencies finally boil down to corporate behaviour and attitude. Such deficiencies can not be cured by regulation. As stated by a member of the European Corporate Governance Forum (2009a;5) instead of trying to master things through regulation an attempt should be made to look into the behavioural patterns to understand what factors are driving the behaviour of market actors ${ }^{20}$. In this respect it is worthwhile to mention that the European Corporate Governance Forum as well as the OECD, the ICGN and the FSA (in the UK) all plead for tougher board evaluations that ensure that governance policies are functioning appropriately. Such evaluation needs to use external input in order to reach the objective to reveal whether the board functions as a group or whether it is dominated by individuals and to what extent the board is up to its huge tasks.

Self-regulation has the great advantage of flexibility, offering the possibility to tailor to the diverging and changing needs of the business world. Those that criticise self regulation, should be reassured because soft law may finally have more teeth than originally assumed. This is certainly the case when jurisprudence is developed with reference to these selfregulatory principles. On top of that, boards of directors and shareholders that formally adhere to the governance principles will considerably increase the strength of self-regulation. However, we may not be blind that self-regulation will need to be complemented with additional regulation. There seems to be a consensus that this will certainly be the case when it comes to transparency and accountability on (executive) remuneration.

\footnotetext{
${ }^{20}$ The Commission is even asked to put some money in research on this issue.
} 


\section{BIBLIOGRAPHY}

ANGELONI I., 2008, Testing Times for Global Financial Governance, Bruegel Essay and Lecture Series, Bruegel Brussels.

DER AUFSICHTSRAT, 2009, Aktienkursorientierte Vergütung wird meist überschätzt, Press Release 3 March 2009, Fachverlag der Verlagsgruppe Handelsblatt GmbH, Düsseldorf.

BAETEN X., 2008, Disclosure on Executive Remuneration, Presentation at ERRC (Executive Remuneration Research Centre) Event Executive Remuneration Disclosure: Observation and Trends, 10 December 2008.

BARKER R., 2008, The UK Model of Corporate Governance: An Assessment from the Midst of a Financial Crisis, IoD Corporate Governance Briefing, October 2008.

BARKER R., 2009, Boardroom independence is not enough, IoD \& ecoDa conference, 27 April 2009

BECHT M., 2009, Corporate Governance and the Credit Crisis, Financial Regulation and Macroeconomic Stability - Key issues for the G20, Centre for Economic Policy Research, London, 31 January 2009

BOSTYN F., 2008, Freaky Freddie \& Funny Fannie, De Standaard, 10 October 2008.

BOTIN E., 2008, Banking's mission must be to serve it's customers, Financial Times, 17 October 2008 .

BZB (Beroepsvereniging van Zelfstandige Bank- en verzekeringsbemiddelaars), 2009, "Het topmanagement van de banken heeft een verpletterende verantwoordelijkheid in de crisis" Interview met Ivan Van de Cloot (Itinera), BZB Nieuwsbrief, 11, p.2.

CEMA (Committee on Economic and Monetary Affairs), 2008, Hearing on Lamfalussy follow-up: future structure on supervision, Brussels, 2 and 3 June May 2008.

CLAERHOUT P. and KILLEMAES D., 2009, “Aandeelhouders straffen is geen oplossing”Jan Huyghebaert (KBC Groep) over de impact en de gevolgen van de financiële crisis, Trends, 19 March 2009, 35 (12): 28-34. 
CLEEREN E., 2008, Geert Noels: "Nous allons survivre à ce choc financier”, L'Echo, 25 October 2008, p.2.

COLMANT B., 2008a, Kredietcrisis test deugdelijkheid boekhoudnormen, De Tijd, 26 April 2008.

COLMANT B., 2008b, Le capitalisme belge face à ses démons, L'Echo, 21 October 2008.

COLMANT B., 2008c, België, welkom in de $21^{\text {ste }}$ eeuw, De Tijd, 17 December 2008, p.16.

DE GRAUWE P., 2009, Banken onderschatten financiële risico's, De Tijd, 29 January 2009.

DE KEULENEER, 2009, La crise financière est d'abord une crise de la gouvernance, L'Echo, 7 February 2009.

DE LAROSIERE, 2009, Report on the future of financial supervision in the EU, 25 February 2009, Brussels.

DENDOOVEN P., 2009, Excessen volgen elkaar steeds sneller op, De Standaard, 3 January 2009.

DUBBINK W. and VAN LIEDEKERKE L. , 2008, De (on)verantwoordelijke organisatie, De Standaard, 8 October 2008.

ECONOMIST INTELLIGENCE UNIT, 2003, Corporate Governance: Business under scrutiny, White Paper, sponsored by KPMG.

EUROPEAN COMMISSION, 2009, Roundtable on Directors' Remuneration, 23 March 2009.

EUROPEAN CORPORATE GOVERNANCE FORUM, 2009a, Minutes of the meeting of 17 February 2009, published by the European Commission on 6 March 2009.

EUROPEAN CORPORATE GOVERNANCE FORUM, 2009b, Statement of the European Corporate Governance Forum on Director Remuneration, 15 March 2009.

L'EXPANSION, 2009, Het nieuwe kapitalisme komt eraan - (Focus) Economische Crisis, Trends, 8 January2009, 35 (2), p.30-35. 
FSA (Financial Services Authority), 2009, FSA publishes code of practice on remuneration policies, Press Release 26 February 2009, http://www.fsa.gov.uk/pages/Library/Communication/PR/2009/032.shtml

GOOREVITCH P.A. and SHINN J., 2005, Political Power \& Corporate Control - The new global politics of corporate governance, Princeton University Press, Princeton.

GRIFFIOEN H., 2009, Lessen van de financiële crisis, ZM Magazine, 7 (2), p.4-8.

HAHN P., 2007, Blame the Bank Boards, The Wall Street Journal, 29 November 2007.

HANDY C., 1995, Trust and the Virtual Organization - How do you manage people whom you do not see?, Harvard Business Review, 73 (3), p.40-50.

ICGN (International Corporate Governance Network), 2008, Statement on the Global Financial Crisis, Press Release 10 November 2008, http://www.icgn.org/news/releases/fcrisis_statement_10nov2008.php

ICGN, 2009a, G20 Leaders Summit: the role of corporate governance in restoring stability, Letter to Prime Minister Gordon Brown by Chairman Peter Montagnon, 23 March 2009.

ICGN, 2009b, Second Statement on the Global Financial Crisis, 23 March 2009.

INTERNATIONAL INSTITUTE FOR FINANCE, 2008, Principles of Conduct for Compensation Policies.

JANSS J., 2009, Vermijd simplismen over nieuw loonbeleid, De Standaard, 6 April 2009.

KILLEMAES D. and MOUTON A., 2008, "Europa heeft het te ver laten komen" - Professor Dirk Heremans schrijft drie behandelingen voor, Trends, 16 October 2008, 34 (42), p. 50-52.

KIRKPATRICK G., 2009, debate GUBERNA, Brussels, 27 March 2009.

KLEIN J-Y., 2008, Crise financière - Les premières leçons, L'Echo, 15 October 2008.

KV, 2009, Nu of nooit voor Europees toezicht, De Tijd, 26 February 2009.

LDV, 2009, Duitsland knaagt aan topsalarissen, De Tijd, 6 March 2009. 
LEMOINE F., 2008, Victimes de la crise financière: où étaient les administrateurs?, Les

Echos, 30 September 2008, p.19,

http://tosca.ccip.fr/IndexedFiles/html/lesechos.4778449.xml.html

MILlMAN G.J., 1999, The Day Traders : The Untold Story of the Extreme Investors and How They Changed Wall Street Forever, Crown Business, New York.

OECD (Organisation for Economic Co-operation and Development), 2009a, OECD Observer, December 2008-January 2009, 270/271.

OECD, 2009b, Corporate Governance Lessons from the Financial Crisis, Directorate for financial and enterprise affairs - Steering Group on Corporate Governance, 23 February 2009.

OECD, 2009c, First Interim Report on the OECD's strategic response to the financial and economic crisis, OECD Council, 11 March 2009.

PIRONET E., 2009, 'A la guerre comme à la guerre' - Interview met Freddy Van den Spiegel, hoofdeconoom Fortis Bank, Knack, 11 March 2009, 39 (11), p.22-26.

RHODES D., STELTER D., SAUMYA S., and KRONIMUS A., 2008, Collateral Damage What Crisis in the Credit Markets Means for Everyone Else, The Boston Consulting Group.

RHODES D., STELTER D., and SAUMYA S., 2008, Collateral Damage - Part 2: Taking Robust Action in the Face of the Growing Crisis, The Boston Consulting Group.

ROGIERS F., 2009, "We zitten nog niet op het keerpunt" - Norbert De Batselier, directeur Nationale Bank, zoekt uitwegen uit de economische crisis, De Morgen, 14 March 2009, p.44.

SARKOZY N., 2008, Discours de M. Le Président de la République, Speech in Zénith de Toulon, 25 September 2008.

SEN A., 2009, Markt alleen volstaat niet, De Tijd, 14 March 2009, p.18.

SOROS G., 2008, De Internationale Kredietcrisis - De toekomst van de financiële markten, Uitgeverij Contact, Amsterdam. 
VAN DE CLOOT I., 2008a, Financieel kapitalisme onder vuur, De Standaard, 1 October 2008, p.24.

VAN DE CLOOT I., 2008b, Financieel kapitalisme onder vuur, Itinera Institute Nota, 2 October 2008, p.1-3.

VAN DE CLOOT I., 2008c, Red het kapitalisme van de kapitalisten, De Tijd, 15 October 2008, p.16.

VAN DEN BERGHE L., 2002, Corporate Governance in a globalising world: convergence or divergence? A European perspective', Kluwer Academic Publishers, 2002.

VELU C., 2009, Evolution, Revolution - or Business Collapse? Understanding, and Reacting to, Business Model Innovation, Video + Transcript, Judge Business School, University of Cambridge, http://sms.cam.ac.uk/media/528047.

VERBEKE L., 2009, 'Governance... also in crisis', Vlerick Leuven Gent Management School Internal Working Paper.

VISSER C., 2008, Maak meer werk van risico's, Het Financieele Dagblad, 28 October 2008.

WARD R.D., 2009, The GM Board Takeover - Are Corporate Boards Obsolete?, Newsletter Boardroom INSIDER, 3 April 2009.

WYMEERSCH E., 2008, Corporate Governance and financial stability, Financial Law Institute Working Paper, $n^{\circ}$ 2008-11, (SSRN 23.10.2008). 